Yüzüncü Y1l Üniversitesi
Tarim Bilimleri Dergisi

Araştırma Makalesi (Research Article)

\title{
Capsicum chinense Türüne Ait Biber Popülasyonunun SSR Molekülerleri ile Karakterizasyonu
}

\author{
Kübra TAŞ ${ }^{* 1}$, Ahmet BALKAYA ${ }^{2}$, Ali Tevfik UNCU ${ }^{3}$ \\ 1,2 Ondokuz Mayıs Üniversitesi, Ziraat Fakültesi, Bahçe Bitkileri Bölümü, Samsun, Türkiye \\ ${ }^{3}$ Necmettin Erbakan Üniversitesi, Fen Fakültesi, Moleküler Biyoloji ve Genetik Bölümü, \\ Konya, Türkiye
}

${ }^{1}$ https://orcid.org/0000-0003-2859-1212 ${ }^{2}$ https://orcid.org/0000-0001-9114-615X ${ }^{3}$ https://orcid.org/0000-0003-4729-5750

*Sorumlu yazar e-posta: kbra.tass55@gmail.com

Makale Bilgileri

Geliş: 26.04 .2021

Kabul: 31.07 .2021

Online Yayınlanma: 15.09 .2021

DOI: $10.29133 /$ yyutbd.928181

\section{Anahtar Kelimeler}

Capsicum chinense,

Karakterizasyon,

SSR,

Genetik çeşitlilik
Öz: Genetik kaynaklarının karakterizasyonu ve çeşitlilik düzeylerinin belirlenmesinde morfolojik tanımlayıcılar ve moleküler analiz yöntemlerinden yararlanılmaktadır. Capsicum chinense biber türü; meyve özellikleri yönünden yüksek düzeyde varyasyon göstermektedir. Bu çalışmada, Capsicum chinense türüne ait biber genetik kaynaklarının (83 genotip) SSR yöntemine göre moleküler karakterizasyonu ile tür içerisindeki mevcut popülasyondaki varyasyon düzeyi ve genetik çeşitlilik düzeylerinin saptanması amaçlanmıştır. Moleküler analizler sonucunda, incelenen 14 SSR primerinden toplam 115 bant elde edilmiştir. Yapılan değerlendirme sonucunda, bantların 66 tanesinin polimorfik (\% 57.4) ve 49 tanesinin ise monomorfik (\% 42.6) olduğu belirlenmiştir. Capsicum chinense türüne ait biber genotipleri, SSR markörleri ile yapılan moleküler analizler sonucunda Ağırlık atanmamış komşu birleştirme yöntemine göre üç farklı heterojen genetik gruba ayrılmıştır. Ayrıca, C. chinense türüne ait biber genotipleri arasında genetik uzaklık değerlerinin 0.15-0.75 arasında değiştiği bulunmuştur. $\mathrm{Bu}$ çalışma sonucunda karakterizasyonu yapılmış olan $C$. chinense türüne ait biber genotiplerinde halen seleksiyon ıslahı çalışmalarına devam edilmektedir.

\section{Molecular Characterization of Capsicum chinense Populations with SSR markers}

\section{Article Info \\ Received: 26.04 .2021 \\ Accepted: 31.07.2021 \\ Keywords \\ Capsicum chinense, \\ Characterization, \\ SSR, \\ Genetic diversity.}

Online Published: 15.09 .2021

DOI: $10.29133 /$ yyutbd.928181

\begin{abstract}
Morphological descriptors and molecular analysis methods were used to identify plant genetic resources and determine genetic diversity levels. Capsicum chinense has a high variation in terms of fruit traits. In this study, it was aimed to identify the plant characteristics of 83 Capsicum chinense genotypes and to determine genetic diversity levels in the existing population within the species by SSR method. As a result of molecular analysis of genotypes of Capsicum chinense species, a total of 115 bands were obtained from 14 SSR markers. As a result of the evaluation, 66 of the bands were polymorphic (57.4\%) and 49 were monomorphic (42.6\%). As a result of analyses made with SSR markers in Capsicum chinense genotypes, it was divided into 3 heterotic main groups according to the Unweighted Neighbor-Joining method. Genetic distance values of $C$. chinense genotypes were found to vary between $0.15-0.75$. It is planned to continue selection breeding studies in $C$. chinense genotypes, which have characterization with this study.
\end{abstract}




\section{Giris}

Biber bitkisi, Solanaceae familyası içerisinde yer alan 98 cinsten birisi olan Capsicum cinsine aittir (Greenleaf, 1986; Eshbaugh, 2012). Günümüzde Capsicum cinsi içerisinde sadece beş tür (C. annuum L., C. baccatum L. var. pendulum, C. chinense Jacq., C. frutescens L. ve C. pubescens Ruiz \& Pav.) kültüre alınmıştır (Eshbaugh, 2012; Barboza ve ark., 2019 ). Bu türler, üç farklı gen merkezinde yaygın olarak rastlanan yabani türlerden zaman içerisinde ortaya çıkan değişimler sonucunda meydana gelmişlerdir. C. chinense ve $C$. frutescens türlerinin gen merkezi, Amazon Havzası olarak kabul edilmektedir (Ramchiary ve ark., 2014).

Biberin orijini, Orta Amerika'dır. Brezilya'da en çok yetiştirilen ve tüketilen acı biber türü, $C$. chinense'dir. $C$. chinense Jacq türü $2 \mathrm{n}=2 \mathrm{x}=24$ genom yapısına sahip olup, 2017 yılında referans genomu yayımlanmıştır. Biber ıslahında özellikle biyotik ve abiyotik stres dayanıklılık/toleransının genetik alt yapısını ve allel çeşitliliğinin birincil kaynağı olarak çeşit 1slah programlarında kullanılmaktadır. (Qin ve ark., 2014; Kim ve ark., 2017). Capsicum chinense Jacq. bitki karakterleri; meyve şekli, rengi ve büyüklüğ̈̈ bakımında yüksek düzeyde çeşitlilik göstermektedir (Bharath ve ark., 2013). Bu tür, Orta ve Güney Amerika ülkelerinde ve Asya'da Çin ve Japonya'da oldukça fazla yayıllış göstermektedir (Eshbaugh, 2012). Günümüzde kültüre alınan formlarının yanı sıra geçit formlarda bulunmaktadır. Bu nedenle $C$. chinense türü; meyve şekli, meyve rengi, meyve büyüklükleri ve acılık seviyeleri yönünden yüksek oranda fenotipik çeşitlilik göstermektedir (Moscone ve ark., 2007).

Genetik kaynaklar, yeni çeşitlerin geliştirilmesinde ve çeşit 1slah programlarının oluşturulmasında bitki ıslahçılarının en büyük yardımcısıdır (Balkaya ve Yanmaz, 2001; Karaağaç ve Balkaya, 2017). Ayrıca bu genetik materyaller yetiştirildikleri farklı ekolojilere adaptasyon yetenekleri, hastalık ve zararlılara karşı dayanıklılık göstermeleri ve istenen birçok kalite özelliğine sahip olmaları nedeniyle de çeşit ıslahı programları için eşsiz nitelikte değerli kaynaklardır (Hawkes, 1983). Islahçılar son yıllarda genetik çeşitlilikten yararlanarak, adaptasyon, verim, kalite, hastalık ve zararlılara dayanıklılık yönünden istenilen özelliklere sahip bitki çeşitlerini seçme veya çeşit geliştirme yolunda önemli düzeyde başarılar elde etmişlerdir (Karaağaç ve Balkaya, 2017). Ortiz ve Delgado (1990), farklı tohum gen bankalarında (UNA, Peru; CATIE, Kosta Rika; INIA, Meksika ve CIRF, Meksika) bulunan Capsicum cinsinin kültürü yapılan beş farklı biber türünde, morfolojik özellikler yönünden incelemeler yapmışlar ve $C$. annuum L., $C$. chinense Jacq., $C$. frutescens L., C. pubescens ve $C$. baccatum L. türüne ait biber genotiplerini çeşit ıslahı çalışmalarında kullanılmak üzere gruplandırmışlardır.

Biber yetiştiriciliği yapılan ülkelerde zaman içerisinde yüksek düzeyde zengin bir genetik çeşitlilik oluşmuş ve bunun sonucunda birçok farklı niteliklere sahip yeni çeşitler meydana gelmiştir. Çeşitli yollarla bir bölgeye gelen bitkisel gen kaynakları, bulunduğu bölgeye zamanla adapte olmakta ve çevre faktörlerinin de etkisiyle zamanla genetik yapısında belirgin fenotipik açılmalar meydana gelmektedir (Karaağaç, 2006). Biberde yabancı tozlanma oranı, çeşitlere göre \% 9-32 oranları arasında değişmektedir (Bayraktar, 1970). Biber tohum üretiminde izolasyon tekniklerine uyulmadığı takdirde yüksek oranda genetik açılmalar meydana gelebilmektedir (Karaağaç ve Balkaya, 2010).

Bitki genetik çeşitlilik düzeylerinin belirlenmesine yönelik çalışmalarda, genetik farklılıkların tam ve doğru olarak ortaya konulmasında hem morfolojik tanımlayıcılar hem de moleküler analiz yöntemlerinden yararlanılmaktadır (Geleta ve ark., 2005). Capsicum türleri, birçok araştırıcı tarafından morfolojik tanımlayıcılar, sitogenetik analizler ve moleküler markörler kullanılarak ayrıntılı olarak incelenmiştir (Conicella ve ark., 1990; Lefebvre ve ark., 1993, 2001; Zewdie ve Zeven, 1997; Geleta ve ark., 2004). Bu çalışmalarda, Capsicum cinsi içerisinde bitkisel özelliklerle ilgili 290'nın üzerinde genin bulunduğu bildirilmiştir. Bu genlerin kalıtım mekanizmaları ile ilgili çalışmalar halen devam etmektedir (Buso ve ark., 2003).

Tarla ve sera denemeleri ile yapılan morfolojik çeşit tanımlama çalışmaları hem uzun zaman almakta hem de bazı morfolojik karakterlerin kalıtım derecesinin düşük olması nedeniyle çevre koşullarından kolaylıkla etkilenmekte, dolayısıyla genotipik özellikleri ile fenotipik özellikleri arasında zamanla belirgin farkl1lkklar oluşabilmektedir. Bunun sonucunda bazen kesin sonuçlara ulaşılamamaktadır (Okumuş ve Balkaya, 2007; Karaağaç ve Balkaya, 2010). Bu sorunun üstesinden gelmek ve islahçının daha doğru ve kesin teşhislere ulaşabilmesi için günümüzde modern biyoteknolojik yöntemlerden yararlanılmaktadır. Son yıllarda birçok farklı moleküler markör tekniği geliştirilmiştir. Bunlardan bazılar1; RFLP (Restriction Fragment Length Polymorphism), RAPD (Random Amplified Polymorphic DNAs), AFLP (Amplified Fragment Length Polymorphisms), SSR (Simple Sequence 
Repeats) ve SNP (Single Nucleotide Polymorphism) teknikleridir. (Röder ve ark., 1995; Geleta ve ark., 2005; Şensoy ve Şahin, 2012; Erdinc ve ark., 2017).

Capsicum chinense Jacq. genomunun genetik haritalarının oluşturulması, genoma spesifik markörlerin geliştirilmesi ve markör verilerinin biber türleri arasında transfer edilebilirlikleri ile karşılaştırmalı haritalama çalışmaları gerçekleştirilmiştir (Kim ve ark., 2017; Uncu 2019; Qin ve ark., 2014; Park ve ark., 2019; Zhu ve ark., 2019). Birçok bilimsel çalışmada; C. chinense gen kaynaklarında farklı moleküler markör sistemleri kullanılarak genotipler arasında genetik çeşitliliğin belirlenmesi, popülasyon yapısı analizleri ile karakterize edilmiştir. Özellikle AFLP, SNP ve SSR markör sistemlerinin $C$. chinense türüne ait gen kaynaklarının karakterizasyonunda çoklukla kullanıldığı bilinmektedir. (Baruah ve ark., 2019; Baba ve ark., 2016; Zhang ve ark., 2016; Moreira ve ark., 2018). C. chinense gen kaynaklarının karakterizasyonuna önemli bir örnek Latin Amerika coğrafyasından elde edilen 112 adet $C$. chinense genotipinin SSR markörleri kullanılarak genetik çeşitlilik ve popülasyon yapısının analiz edildiği çalışmadır (Moses ve ark., 2014).

Kromozomların üzerinde genlerin bulunduğu özel kısımlar için fazla oranda allel üretebilmesi, tekrarlanabilir olması, aynı türe dahil olan çeşitler ile aynı cinse dahil türler arasında aktarımın sağlanabilmesi ve ülkelerin veri tabanlarının kıyaslanmasına izin vermesi gibi oldukça önemli avantajlara sahip olması nedeni ile SSR tekniği, bitki türlerinin tanımlanmasında önceki DNA primerlerin kullanıldığ 1 tekniklere (RFLP, RAPD, AFLP vb.) göre daha yaygın kullanılmaktadır (Acunalp, 2012). Araştırıcılar, SSR yönteminin sağladığı bu avantajlardan dolayı farklı bitki tür ve çeşitlerinde oldukça başarılı bir şekilde uygulanabildiğini bildirmişlerdir (Röder ve ark., 1995; Geleta ve ark., 2005).

Bu çalışma ile Amerika Tarım Bakanlığı Tohum Gen Bankasında kayıtlı bulunan C. chinense türüne ait dünya koleksiyonunun SSR markörleri kullanılarak karakterize edilmesi, genotipler arasındaki genetik uzaklıkların belirlenmesi ve birbirleriyle olan akrabalık ilişkilerinin ayrıntılı olarak belirlenmesi amaçlanmıştır.

\section{Materyal ve Yöntem}

Araştırma, 2019 yılında Ondokuz Mayıs Üniversitesi Ziraat Fakültesi Bahçe Bitkileri Bölümü, Tarımsal Biyoteknoloji Bölümü'nde ve Necmettin Erbakan Üniversitesi Fen Fakültesi Moleküler Biyoloji ve Genetik Bölümü’nde koordineli olarak yürütülmüştür. Bitkisel materyal olarak Amerika Tarım Bakanlığı Tohum Gen Bankasından (USDA-ARS-National Plant Germplasm System NPGS) temin edilen Capsicum chinense türüne ait 83 biber genotipi kullanılmıştır (Çizelge 1). C. chinense genotiplerinde genetik materyallerde bir generasyon kendileme yapılmıştır. $C$. chinense türüne ait biber fideleri, Ondokuz Mayıs Üniversitesi Ziraat Fakültesi Bahçe Bitkileri Bölümü sıcaklık kontrollü sera ünitesinde yetiştirilmiştir. Daha sonra 4-5 gerçek yaprağa ulaşan fideler deneme arazisine 50 x $50 \mathrm{~cm}$ sıra arası ve sıra üzeri mesafe ile dikilmiştir. Arazide dikimi yapılmış genç biber yapraklarından her bir populasyonu temsil edecek şeklide bitkilerden bulk şeklinde örnekler alınarak laboratuvara getirilmiş ve DNA izolasyonu yapılıncaya kadar $-80^{\circ} \mathrm{C}$ 'de derin dondurucuda muhafaza edilmiştir.

\subsection{Moleküler Karakterizasyon}

Bitkisel genetik materyalde DNA izolasyonu, 14.01.2019 tarihinde ZR Plant/Seed DNA MiniPrep kit kullanılarak gerçekleştirilmiştir. İzolasyonu gerçekleştirilen DNA'ların kalitesi ve miktarları NanoDrop spektrofotometre'de ölçülmüştür. Bitkisel materyallerden izole edilen DNA'lar seyreltildikten sonra sentetik olarak hazırlanmış SSR primerleri ve tüm reaksiyon komponentleri eklenerek Polimeraz Zincir Reaksiyonu Sicaklık Döngü cihazı (PCR thermal cycler) içerisine yerleştirilmiştir. Çalı̧̧mada kullanılan SSR markörleri, literatürde biberde daha önce farklı popülasyonlarda başarıyla uygulanan markörlerdir (Çizelge 2) (Lee ve ark., 2004; Lee ve ark., 2005; Yi ve ark., 2006). PCR uygulamas1, 0.2 ml'lik mikro tüplerde $25 \mu \mathrm{l}$ ' lik (Buffer $2 \mu \mathrm{l}, \mathrm{MgCl}_{2} 1.5 \mu \mathrm{l}$, Taq polimeraz enzimi $0.25 \mu \mathrm{l}$, dNTP karışımı $0.2 \mathrm{mM}$, Primer F $0.75 \mu \mathrm{l}$, Primer R $0.75 \mu \mathrm{l}$, DNA $1 \mu \mathrm{l}, \mathrm{ddH}_{2} \mathrm{O}$ ) toplam reaksiyon hacminde gerçekleştirilmiştir. PCR cihazında PCR ürünleri ilk olarak DNA denatürasyonu için, $94{ }^{\circ} \mathrm{C}$ 'de 10 dakika; $94{ }^{\circ} \mathrm{C}^{\prime}$ de 30 saniye ( 35 döngü), $55^{\circ} \mathrm{C}$ 'de 30 saniye (primerlere 
göre bu sıcaklık dereceleri değişiklik gösterebilmektedir) primer sıcaklıkları ve uzama için $72{ }^{\circ} \mathrm{C}$ 'de 45 saniye, son aşamada ise uzama $72{ }^{\circ} \mathrm{C}$ 'de 10 dakika olarak ayarlanmıştır. Daha sonrasında, PCR ürünleri görüntüleneceği zamana kadar $-20^{\circ} \mathrm{C}$ 'de bekletilmiştir.

Çizelge 1. C. chinense türüne ait gen havuzunda yer alan biber genotiplerinin aksesyon numaraları ve orijinleri

\begin{tabular}{|c|c|c|c|c|c|}
\hline $\begin{array}{c}\text { Çalışma } \\
\text { Kodu }\end{array}$ & Aksesyon Numarası & Orijin & $\begin{array}{c}\text { Genotip } \\
\text { Kodu }\end{array}$ & Aksesyon Numarası & Orijin \\
\hline $\mathrm{CC} 1$ & PI 15922301 & ABD & CC39-2 & PI 28143001 & Bolivya \\
\hline $\mathrm{CC} 2$ & PI 21391601 & Bolivya & CC39-3 & PI 28143001 & Bolivya \\
\hline $\mathrm{CC} 3$ & PI 21573601 & Peru & CC39-4 & PI 28143001 & Bolivya \\
\hline $\mathrm{CC} 4$ & PI 24466701 & Hindistan & CC40-1 & PI 31501301 & Peru \\
\hline $\mathrm{CC} 5$ & PI 25708501 & Kolombiya & CC40-2 & PI 31501301 & Peru \\
\hline CC6 & PI 25712901 & Kolombiya & CC40-3 & PI 31501301 & Peru \\
\hline $\mathrm{CC} 7$ & PI 25714501 & Peru & CC40-4 & PI 31501301 & Peru \\
\hline CC8 & PI 26047001 & Peru & $\mathrm{CC} 47$ & PI 23805301 & Meksika \\
\hline CC9 & PI 26048502 & Bolivya & CC50 & PI 49797601 & Filipinler \\
\hline $\mathrm{CC} 10$ & PI 26048601 & Bolivya & CC51 & PI 24166901 & ABD \\
\hline $\mathrm{CC} 11$ & PI 26050801 & Peru & CC51-3 & PI 24166901 & $\mathrm{ABD}$ \\
\hline $\mathrm{CC} 13$ & PI 28139301 & Meksika & CC52 & PI 65374701 & Venezuela \\
\hline CC14 & PI 28141701 & Filipinler & CC54 & PI 65367702 & Peru \\
\hline $\mathrm{CC} 16$ & PI 28143501 & ABD & CC55 & PI 65367602 & Peru \\
\hline $\mathrm{CC} 17$ & PI 28144001 & Venezuela & CC56 & PI 64548703 & Hindistan \\
\hline $\mathrm{CC} 18$ & PI 31501901 & Peru & CC57 & PI 25706801 & Kosta Rika \\
\hline CC19 & PI 31502302 & Peru & CC59 & PI 63965502 & Kosta Rika \\
\hline $\mathrm{CC} 20$ & PI 32272101 & Hindistan & CC60 & PI 64555501 & Meksika \\
\hline CC21 & PI 40672501 & Kosta Rika & CC61 & PI 59392502 & Bolivya \\
\hline $\mathrm{CC} 22$ & PI 43853201 & Belize & CC62 & PI 58525304 & Güney Kore \\
\hline $\mathrm{CC} 23$ & PI 43863602 & Meksika & CC63 & PI 24166801 & Ekvator \\
\hline $\mathrm{CC} 24$ & PI 43941601 & Bolivya & CC65 & PI 25706401 & Ispanya \\
\hline $\mathrm{CC} 25$ & PI 43943201 & G. Kore & CC66 & Grif 926101 & Kosta Rika \\
\hline $\mathrm{CC} 26$ & PI 58527802 & Ekvator & CC68 & PI 43941901 & Meksika \\
\hline $\mathrm{CC} 27$ & PI 25715801 & Peru & CC69-1 & PI 25712601 & Kolombiya \\
\hline $\mathrm{CC} 28$ & PI 66656201 & Meksika & CC69-2 & PI 25712601 & Kolombiya \\
\hline CC-29 & PI 26049101 & ABD & CC69-3 & PI 25712601 & Kolombiya \\
\hline CC29-1 & PI 26049101 & $\mathrm{ABD}$ & CC69-4 & PI 25712601 & Kolombiya \\
\hline CC-30 & PI 66656101 & Bolivya & $\mathrm{CC} 72$ & PI 44163501 & Brezilya \\
\hline CC31 & PI 43863501 & Peru & CC72-4 & PI 44163501 & Brezilya \\
\hline CC33 & PI 43946701 & Hindistan & $\mathrm{CC} 76$ & PI 26046502 & Arjantin \\
\hline CC34 & PI 65374602 & Kolombiya & $\mathrm{CC} 78$ & Grif 919302 & Kolombiya \\
\hline $\mathrm{CC} 35$ & Grif 930801 & Kolombiya & CC79 & PI 66654701 & Guatemala \\
\hline CC36 & PI 63965704 & Peru & CC82-1 & PI 26047701 & Peru \\
\hline CC37 & PI 48559301 & Peru & CC82-2 & PI 26047701 & Peru \\
\hline CC38 & PI 20902801 & Bolivya & CC82-3 & PI 26047701 & Peru \\
\hline CC $38-2$ & PI 20902801 & Bolivya & CC82-4 & PI 26047701 & Peru \\
\hline CC39-1 & PI 28143001 & Bolivya & & & \\
\hline
\end{tabular}

PCR reaksiyonları sonucu $C$. chinense genotiplerine ait DNA örneklerinden; çoğaltılmış olan SSR markörleri Qiaxcel Fragment Analyzer (Qiagen Sample\&Assay Technologies) kapiler elektroforez sistem ile Qiaxcel DNA High Resolution Kiti, QX DNA Size Marker 25-500 bp, v2.0 (Qiagen) boy standard1 ve QX Alignment Marker 15 bp/600 bp (Qiagen) hizalama standard1 kullanılarak OM800 yürütme ve ayırma programı ile yüksek çözünürlükte polimorfik allellerin belirlenmesi için yürütülmüş ve QIAxcel ScreenGel Software (Qiagen) yazılımı kullanılarak görüntülenerek manuel olarak skorlanmıştır. 
Çizelge 2. PCR çalışmalarında kullanılan SSR primerleri ve baz dizinleri

\begin{tabular}{|c|c|c|}
\hline Markör ismi & İleri primer $\left(5^{\prime} \rightarrow 3^{\prime}\right)$ & Geri primer $\left(5^{\prime} \rightarrow 3^{\prime}\right)$ \\
\hline EPMS-596 & CTCGTGCCGTATTTCTGTCA & AAGGGCGTGTTTGGTATGAA \\
\hline EPMS-600 & ATGGGTACGTGTTTGGGGTA & ACTTTATTCCTCGTGCCGAA \\
\hline EPMS-601 & AAATTGAGAACATCGGTGCC & TAAAGAAAGAGCCTCGTGCC \\
\hline EPMS-603 & GCGGTTCCCTATTTGAAGAA & ATAGGGGGAATTGGGTTCC \\
\hline EPMS-628 & TGCTCCTTAAGACTGGCACC & GGGTTCGGCTCTGTTATTGA \\
\hline EPMS-629 & GCTCGAGGGAGAGAGACTGT & GGTCATATGTTTCCATGGGC \\
\hline EPMS-642 & CAACTTCGCGTTATTGTCCA & AGGGCGGACAAAGAAGATTT \\
\hline EPMS-643 & CCAAGATCAACTCTTACGCTAT & ССССТСAAGAATTСССТССАТ \\
\hline EPMS-648 & TGTAAAATAAAATAAGGCTAA & CAAGAAAGTGTGCCCCAAAT \\
\hline EPMS-649 & AAGGGTTCTCGAGGAAATGC & TCAATCCCAAAACCATGTGA \\
\hline EPMS-650 & CATGGGTGAGGGTACATGGT & AGAGGGAAGGGTTATTTGCC \\
\hline EPMS-654 & TTCCACTCTTCGAAGCACCT & GGTAGGGTTTAACACCGCCT \\
\hline EPMS-658 & CCTTGAGTAGGCGCACAAAT & TTCCTCATTGCTTTTCCCAC \\
\hline EPMS-670 & TCACAAAGATGGAGAAGGGAA & CAATCACTGTCACTGCTACTGCT \\
\hline EPMS-683 & AAATGGATCCCAACAACCAA & GGAGTTGAAAACGGTGGAGA \\
\hline EPMS-697 & ATGTCGCTCGCAATTTCACT & CGTAGGGAGGAGCGATAGAG \\
\hline EPMS-704 & GGTCCTCTGATTGGCAACAT & GACCTGAAATTGGAGCAAACA \\
\hline EPMS-705 & TCAACTAGATCCACCACGCA & TAACCCGTTGCTCACACTCA \\
\hline EPMS-725 & TTGAATCGTTGAAGCCCATT & ATCTGAAGCTGGGCTCCTTT \\
\hline EPMS-745 & GTTGTTGGGTGGTACTTGGG & GGAAGATCTCAAATGGGTCG \\
\hline EPMS-747 & CATTGGACGGTTGGTTCTCT & TGGAATTGGAACTTCAAGCA \\
\hline EPMS-755 & CGCTCGCTACCCTTTCATTA & AATTTCGGAAGGGCAAAGAT \\
\hline EPMS-762 & CGGCGAGATATGGACTTGAT & CCCACGTTATACCATCCAGG \\
\hline EPMS-773 & CGAGCAACTCCСТCTTATCG & TCGAATAGCACGCACGTTAG \\
\hline EPMS-923 & CAAAACCAAATAGGTCCCCC & CGCGCAATAATTCAATATCG \\
\hline
\end{tabular}

\subsection{C. chinense Popülasyonunda Genetik Çeşitlilik Düzeyinin Belirlenmesi}

Genotiplere ait SSR markör allelleri mevcut (1) veya yok (0) ve kayıp veri (9) olarak skorlanmıştır. Bu veriler, Nei'nin genetik benzerlik indeksinin (The Nei index of genetic similarity) hesaplanmasında kullanılmıştır (Nei, 1973). Polimorfik markör verileri moleküler genetik çeşitliliği analiz etmek için DARwin 6 (http://darwin.cirad.fr) bilgisayar programı kullanılarak analiz edilmiştir. Markör skorlama verileri benzememezlik hesab1, her bir genotip arasında Dice katsayısı ile hesaplanmıştır. Ağırlık atanmamış komşu birleştirme yöntemi kullanılarak bir genetik çeşitlilik ağacı çizilmiştir. Ayrıca yine aynı yazılım kullanılarak genotiplere ait allel verisi Temel Koordinat Analizi (PCoA) yapılmıştır. Mantel testi benzememezlik hesabı ile çizilen çeşitlilik ağacının arasındaki korelasyonu test etmek üzere gerçekleştirilmiştir.

\section{Bulgular ve Tartışma}

Çalışmada, toplam 83 C. chinense biber genotipi SSR yöntemi ile 25 adet markör kullanılarak incelenmiştir. Markörlerden 11 tanesinden tekrarlanabilir kalitede amplifikasyon elde edilememiştir. Amplifikasyonu oluşturan 14 markörden, toplam 115 bant elde edilmiştir. Yapılan değerlendirme sonucunda, bantların 66 tanesinin polimorfik (\% 57.4) ve 49 tanesinin ise monomorfik (\% 42.6) yapida olduğu belirlenmiştir (Çizelge 3, Şekil 1). Çalışma kapsamında tespit edilen markör başına düşen polimorfizim yüzdesi, Baruah ve ark. (2019) ve Zhang ve ark. (2016) yaptıkları çalışmalar ile benzerlik göstermektedir. 
Çizelge 3. Capsicum chinense türüne ait biber popülasyonunda SSR analizi sonucunda 14 markörden elde edilen bantların sayısı ve dağılışları

\begin{tabular}{ccccc}
\hline Markör Adı & Toplam Bant Sayısı & $\begin{array}{c}\text { Polimorfik Bant } \\
\text { Sayıs (Allel) }\end{array}$ & $\begin{array}{c}\text { Monomorfik Bant } \\
\text { Sayıs }\end{array}$ & $\begin{array}{c}\text { Alel } \\
\text { Büyüklükleri } \\
\text { (bç) }\end{array}$ \\
\hline EPMS-596 & 5 & 3 & 2 & $114-138$ \\
EPMS-600 & 8 & 4 & 4 & $98-142$ \\
EPMS-601 & 7 & 6 & 1 & $166-193$ \\
EPMS-603 & 9 & 5 & 4 & $112-204$ \\
EPMS-628 & 11 & 7 & 3 & $160-196$ \\
EPMS-649 & 7 & 4 & 5 & $137-219$ \\
EPMS-650 & 9 & 4 & 7 & $119-182$ \\
EPMS-705 & 9 & 2 & 2 & $144-157$ \\
EPMS-725 & 7 & 3 & 1 & $123-177$ \\
EPMS-745 & 5 & 6 & 6 & $119-163$ \\
EPMS-747 & 7 & 2 & 2 & $120-163$ \\
EPMS-755 & 8 & 7 & 6 & $117-136$ \\
EPMS-762 & 9 & 8 & 49 & $124-182$ \\
EPMS-773 & 14 & 66 & & \\
\hline Toplam & 115 & & & \\
\hline
\end{tabular}

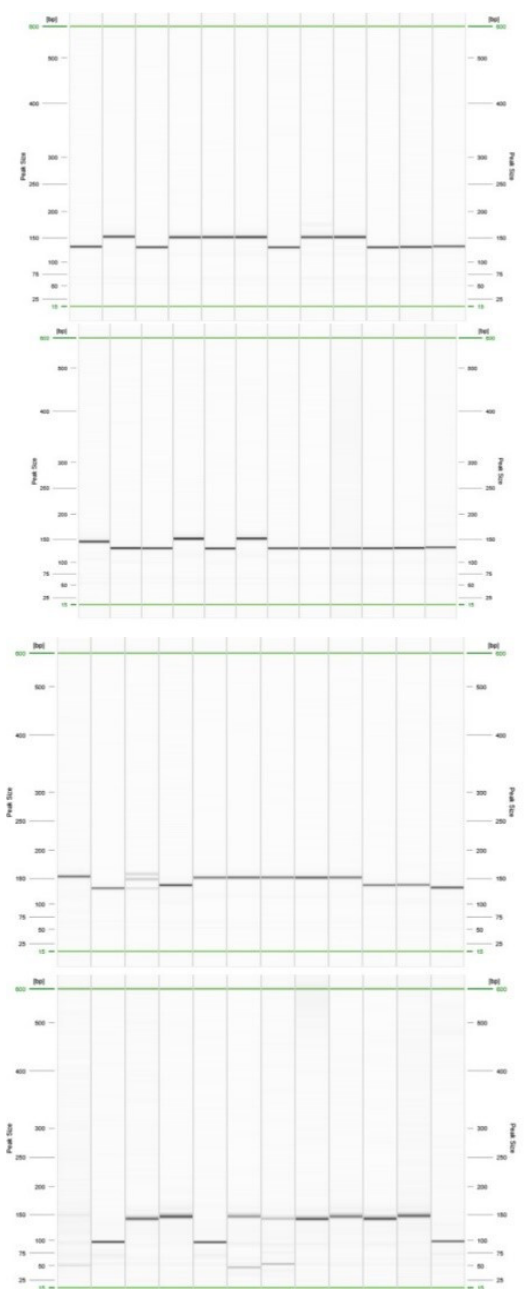

Şekil 1. C. chinense türüne ait biber genotiplerinde EPMS-773 SSR markörü ile elde edilen bantların Qiaxcel Fragment Analyzer yürütmesinin QIAxcel ScreenGel Software görünümü. 
Araştırma sonucunda incelenen $C$. chinense türüne ait biber genotipleri arasında DARwin 6 programı ile $C$. chinense türüne ait biber genotiplerinin genetik uzaklık değerleri hesaplanmıştır. Capsicum chinense türüne ait tüm genotipler arasında genetik uzaklık değerlerinin, 0.15-0.75 arasında olduğu tespit edilmiştir. Elde edilen sonuçlara göre en düşük genetik uzaklık değeri CC54 ve CC40-3 genotipleri arasında 0.15 ve en yüksek genetik uzaklık değeri ise CC79 ve CC2 genotipleri arasında 0.75 olarak bulunmuştur. Araştırma kapsamında kullanılan C. chinense türüne ait biber gen kaynaklarının ortalama genetik uzaklığ 0.44 olarak hesaplanmıştır. Çalışma kapsamında hesaplanan ortalama uzaklık değeri, incelenen gen havuzunun yüksek bir genetik çeşitliliği barındıran bir genetik alt yapıdan geldiğini işaret etmektedir. Bu durum hem çalışılan türün karakteri hem de dünya gen koleksiyonunu temsil eden bir genetik havuzun kullanılmasının sonucudur. Kullanılan gen havuzu, tür içeresinde bulunabilecek olası her lokus için potansiyel tüm allelleri taşıma ihtimaline sahip eşsiz bir gen koleksiyonu niteliğindedir. Araştırma kapsamasında kullanılan gen havuzuna benzer özelliklere sahip gen kaynaklarının karakterizasyonu çalışmalarında elde edilen genetik uzaklık verilerine benzer ve doğrular nitelikte sonuçlar elde edilmiştir (Baba ve ark., 2016; Zhang ve ark., 2016; Moreira ve ark., 2018; Baruah ve ark., 2019). Moleküler karakterizasyon sonucunda toplam 83 genotipten elde edilen polimorfik bantlardan hesaplanan benzerlik oranları kullanılarak oluşturulan dendrogram, Şekil 2'de verilmişstir.

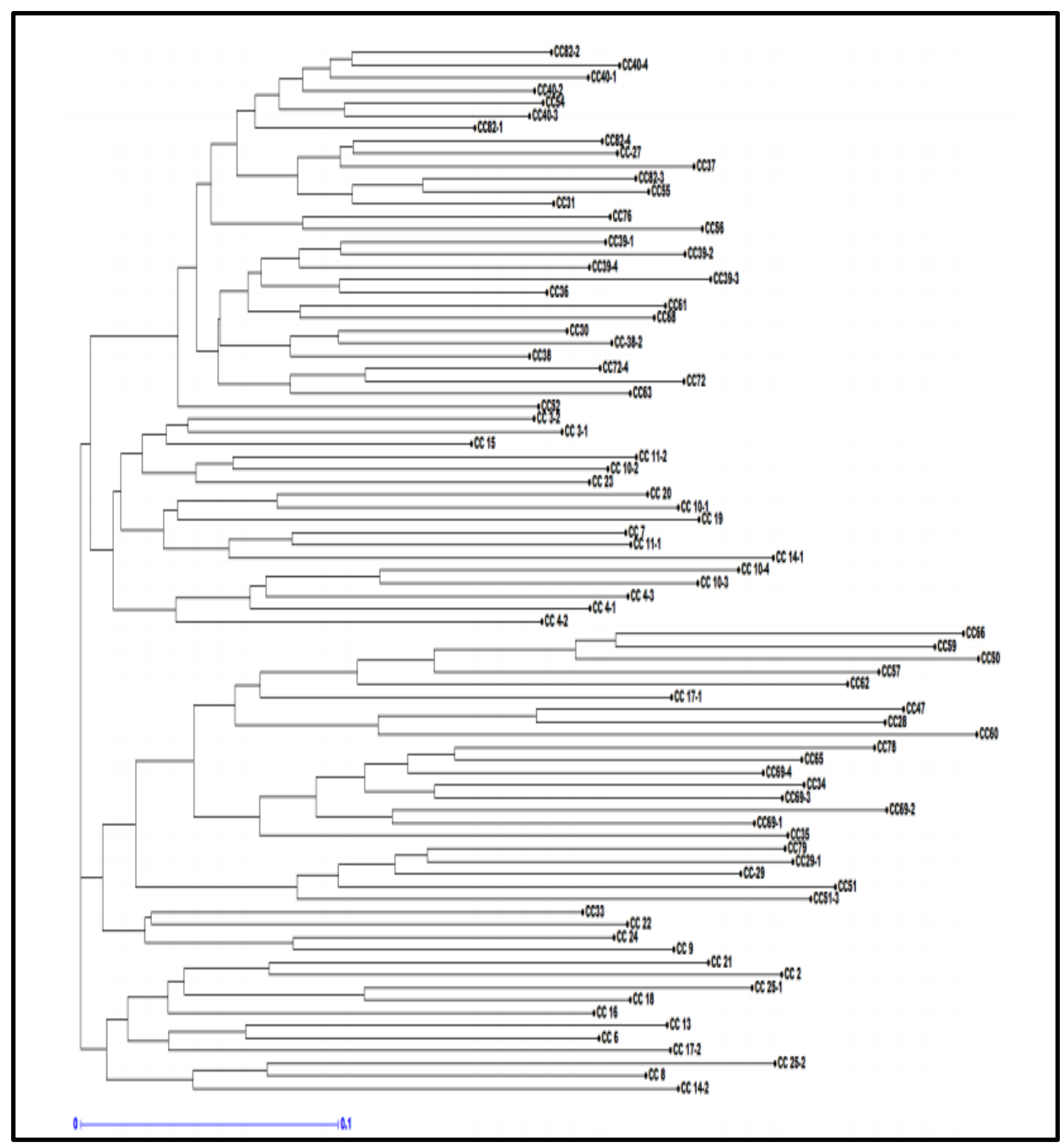

Şekil 2. Ağıllık atanmamış komşu birleştirme yöntemi (Unweighted Neighbor-Joining [NJ]) metodu ile oluşturulmuş $C$. chinense türüne ait biber genotipleri arasındaki genetik ilişkileri gösteren dendrogram. 
Uzaklık matrisi ile genetik benzerlikler (NJ) arasındaki korelasyon Mantel test ile belirlenmiștir $(\mathrm{r}=0.92)$. Genetik uzaklık matrisi verileri ile dendrogram birlikte değerlendirildiğinde sonuçların uyumlu olduğu görülmektedir. Dendrogram incelendiğinde $C$. chinense türüne ait biber genotiplerinin 3 ana grup içerisinde kümelendikleri belirlenmiştir (Çizelge 4). Moses ve ark. (2014) tarafindan Latin Amerika kökenli bir $C$. Chinense genotip koleksiyonunun moleküler genetik çeşitliliğinin incelendiği çalışma sonuçları, bu çalışma ile benzer şekilde genotiplerin üç grupta toplandığını göstermektedir.

Çizelge 4. C. chinense biber popülasyonlarının küme analizi sonucunda elde edilen grup ve alt grupların dağılışı

\begin{tabular}{|c|c|c|c|}
\hline Grup & $\begin{array}{c}\text { Alt } \\
\text { Grup }\end{array}$ & Genotipler & $\begin{array}{l}\text { Toplam } \\
\text { Genotip } \\
\text { Say1S1 }\end{array}$ \\
\hline A & 5 & $\begin{array}{c}\text { CC82-2, CC40-4, CC40-1, CC40-2, CC54, CC40-3, CC82-1, } \\
\text { CC82-4, CC27, CC37, CC82-3, CC55, CC31, CC76, CC56, } \\
\text { CC39-1, CC39-2, CC39-4, CC39-3, CC36, CC61, CC68, CC30, } \\
\text { CC38-2, CC38, CC72-4, CC72, CC63, CC52, CC3-2, CC3-1, } \\
\text { CC15, CC11-2, CC10-2, CC23, CC20, CC10-1, CC19, CC7, } \\
\text { CC11-1, CC14-1, CC10-4, CC10-3, CC4-3, CC4-1, } \\
\text { CC4-2 }\end{array}$ & 46 \\
\hline B & 4 & $\begin{array}{l}\text { CC66, CC59, CC50, CC57, CC62, CC17-1, CC47, CC28, CC60, } \\
\text { CC } 78, \text { CC65, CC69-4, CC 34, CC69-3, CC69-2, CC69-1, CC 35, } \\
\text { CC79, CC29-1, CC29, CC51, CC51-3, CC } 33, \text { CC22, CC24, CC9 }\end{array}$ & 26 \\
\hline $\mathrm{C}$ & 3 & $\begin{array}{c}\mathrm{CC} 21, \mathrm{CC} 2, \mathrm{CC} 25-1, \mathrm{CC} 18, \mathrm{CC} 16, \mathrm{CC} 13, \mathrm{CC} 6, \mathrm{CC} 17-2, \mathrm{CC} 25- \\
\text { 2, CC8, CC14-2 }\end{array}$ & 11 \\
\hline Toplam & 12 & & 83 \\
\hline
\end{tabular}

Dendrogramda Grup A içerisinde, 5 alt grubun yer aldığ belirlenmiştir. En fazla biber genotipi (46 genotip) Grup A içerisinde bulunmuştur. Grup A'dan sonra en fazla alt grup, Grup B'de belirlenmiştir. Dendrogram incelendiğinde, Grup C'nin 3 alt gruba ayrıldığ 1 ancak en az sayıda biber genotiplerinin kümelendiği grup olduğu bulunmuştur. Bu grup içerisinde yer alan genotiplerin Grup A ve Grup B'ye göre daha uzak genetik uzaklığa sahip oldukları belirlenmiştir.

C.chinense türüne ait biber gen havuzunun 3 farklı heterotik grup oluşturması nedeniyle gelecekte heterosis 1slahında yeni biber çeşitlerin geliştirilmesinde yararlanma potansiyeli bulunmaktadır. Ayrıca, araştırma sonucunda farklı alt gruplar içerisinde yer alan biber genotiplerinde var olan genetik çeşitliliği büyük oranda temsil eden çekirdek koleksiyonların oluşturulması da planlanmaktadır. Böylece benzer genotiplerin çeşit ıslah programları içerisinde duplikasyonları önlenmiş olacaktır.

Araştırma sonucunda, elde edilen moleküler benzerlik oranları ile daha önceden başka bir çalışmada tespit edilmiş olan morfolojik yönden benzerlik oranları arasında direkt bir ilişkisinin olmadığ1 ortaya çıkmıştır. Bu nedenle $C$. chinense türüne ait biber genotiplerinde hem morfolojik özellikler hem de moleküler analiz sonuçlarına göre tek başına genotiplerin orijinleri ile ilişkilendirilmesi mümkün olmamıştır. Bu durum, $C$. chinense türünde çalışmalar yürüten Baba ve ark. (2016) ve Moreira ve ark. (2018)'nın sonuçları ile de benzerlik göstermiştir.

Temel Koordinat Analizi (PCoA) sonucunda biber genotipleri 4 ana grup içerisinde kümelenmiştir (Şekil 3). Temel Koordinat Analizi sonucunda oluşan kümelerde yer alan genotiplerin dağılışı ile dendrogram grupları içerisinde oluşan kümelenmeler çoğunlukla uyum sağlamıştır. PCoA analizi genel olarak bu çalışmada $C$. chinense türüne ait biber popülasyonlarında SSR markörleriyle dünyanın farklı yerlerinden toplanmış olan $C$. chinense biber genotipleri arasındaki coğrafi bir kümelenmeyi ortaya çıkarmıştır. PCoA, ölçülen değişkenler açısından popülasyonlara ait genotipler arasındaki benzerlikleri bir koordinat üzerinde göstermiştir (Şekil 3). 


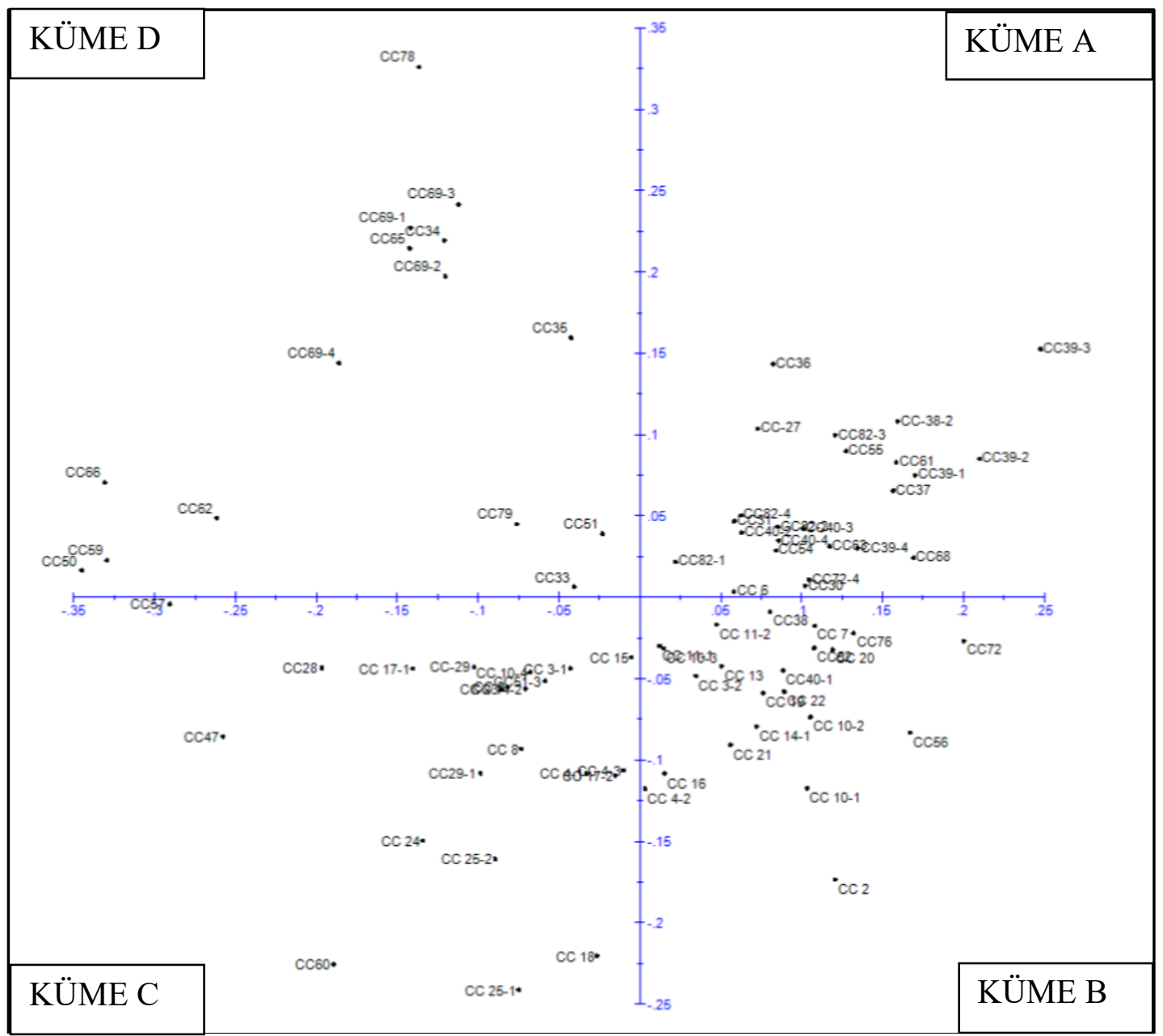

Şekil 3. Capsicum chinense türüne ait biber genotiplerinin PCoA (Temel Koordinat Analizi) grafiği.

\section{Sonuç}

C. chinense türü, Capsicum cinsi içerisinde yer alan en önemli biber türlerinden birisidir. Günümüzde kültüre alınan formlarla birlikte yabani ve geçit formları da bulunmaktadır. Bu nedenle, $C$. chinense türü içerisinde yer alan biber genotipleri; meyve şekli, meyve rengi, meyve büyüklükleri ve acılık seviyeleri yönünden yüksek düzeyde genetik çeşitlilik göstermektedir. Birçok araştırıcı, $C$. chinense türünün biyotik ve abiyotik stres koşullarına dayanıklılık yönünden önemli bir genetik kaynak olduğunu bildirmişlerdir (Hawkes, 1983; Yoon ve ark., 2006; Fonseca ve ark., 2008). Bu araştırma sonucunda, $C$. chinense türüne ait biber popülasyonunda moleküler analizlerde $14 \mathrm{SSR}$ markörlerinden toplam 115 bant elde edilmiştir. Ağırlık atanmamış komşu birleştirme yöntemine göre biber genotipleri, 3 ana gruba ayrılmıştır. Farklı uzunluklarda dendrogram grupları, $C$. chinense türüne ait biber genotiplerinin genetik farklılıklarının oldukça yüksek düzeyde olduğunu göstermiştir.

$\mathrm{Bu}$ araştırma, $C$. chinense biber çeşit ıslahında türe ait başlangıç popülasyonunun moleküler yöntemler ile ayrıntılı olarak tanımlanmasını kapsayan çeşit ıslah programının başlangıç aşamasını oluşturmaktadır. Önümüzdeki yıllarda popülasyon içerisinden seleksiyon 1slahı ile seçilecek üstün nitelikli genetik materyallerin farklı ıslah amaçları doğrultusunda değerlendirilmesi planlanmaktadır.

\section{Teşekkür}

Bu araştırma, Kübra Taş’ın Ondokuz Mayıs Üniversitesi, Lisansüstü Eğitim Enstitüsü, Bahçe Bitkileri Ana Bilim Dalında tamamlanmış olan Yüksek Lisans tez çalışmasının bir kısmından üretilmiştir. 


\section{Kaynakça}

Acunalp, S. (2012). Ekonomik öneme sahip yerli kiraz (Prunus avium L.) genotiplerinin SSRs (Simple Sequence Repeats)'a dayalı genetik karakterizasyonu. Yüksek Lisans Tezi, Ankara Üniversitesi, Biyoteknoloji Enstitüsü, Ankara.

Baba, V.Y., Rocha, K. R., Gomes, G. P., de Fátima Ruas, C., Ruas, P. M., Rodrigues, R., \& Gonçalves, L. S. A. (2016). Genetic diversity of Capsicum chinense accessions based on fruit morphological characterization and AFLP markers. Genetic resources and crop evolution, 63 (8), 1371-1381.

Balkaya, A., \& Yanmaz, R. (2001). Bitki genetik kaynaklarının muhafaza imkanları ve tohum gen bankalarının çalışma sistemleri. Ekoloji Çevre Dergisi, 10(39), 25-30.

Barboza, G. E., Garcia, C. C., Gonzalez, S. L., Scaldaferro, M., \& Reyes, X. (2019). Four new species of Capsicum (Solanaceae) from the tropical Andes and an update on the phylogeny of the genus. PloS one, 14 (1).

Bayraktar, K. (1970). Sebze Yetiştirme. Cilt II Kültür Sebzeleri. Ege Üniversitesi Ziraat Fakültesi Dergisi, 169- 479.

Baruah, J., Pandey, S. K., Sarmah, N., \& Lal, M. (2019). Assessing molecular diversity among high capsaicin content lines of Capsicum chinense Jacq. using simple sequence repeat marker. Industrial Crops and Products, 141, 111769.

Bharath, S. M., Cilas, C., \& Umaharan, P. (2013). Fruit trait variation in a caribbean germplasm collection of aromatic hot peppers (Capsicum chinense Jacq.). Hortscience, 48(5), 531-538.

Buso, G. S. C., Amaral, Z. P. S., Bianchetti, L. B. M., Flavia, R. B., \& Ferreira, M. E. (2003). Genetic variability and phylogenetic analysis of Brazilian species of Capsicum.Capsicum and Eggplant Newsletter, 22, 13-16.

Conicella, C., Errico, A., \& Saccardo, F. (1990). Cytogenetic and isozyme studies of wild and cultivated Capsicum annuum. Genome, 33, 279-282.

Erdinc, C., Turkmen, O., Demir, S., \& Sensoy, S. (2017). Determination of the anthracnose (Colletotrichum lindemuthianum (Sacc. and Magn.) Lambs. Scrib.) resistance in some Turkish bean genotypes by artificial inoculation and molecular methods. JAPS, Journal of Animal and Plant Sciences, 27(1), 175-18.

Eshbaugh, W. H. (Vincent M. Russo) (2012). The taxonomy of the genus Capsicum. In: Peppers Botany, Production and Uses. CAB International, 14-28.

Fonseca, R. M., Lopes, R., Barros, W. S., Lopes, M. T. G., \& Ferreira, F. M. (2008). Morphologic characterization and genetic diversity of Capsicum chinense Jacq. accessions along the upper Rio Negro-Amazonas. Embrapa Amazônia Ocidental-Artigo em periódico indexado (ALICE).

Geleta, N., Daba, C., \& Gebeyehu, S. (2004). Determination of plant proportion and planting time in maize-climbing bean intercropping system. Proc. $10^{\text {th }}$ Annual Conference of the Crop Science Society of Ethiopia, 176-182.

Geleta, L. F., Labuschagne, M. T., \& Viljoen, C. D. (2005). Genetic variability in pepper (Capsicum annuum L.) estimated by morphological data and amplified fragment length polymorphism markers. Biodiversity and Conservation, 14, 2361-2375.

Greenleaf, W. H. (1986). Pepper breeding. Breeding vegetable crops. CAP International. The Cambridge University Press, United Kingdom, 76-82.

Hawkes, J. G. (1983). The diversity of crop plants. Harvard University Press, Cambridge, Massachusetts, 184.

Karaağaç, O. (2006). Bafra kırmızı biber gen kaynaklarının (Capsicum annuum var. conoides Mill.) karakterizasyonu ve değerlendirilmesi. Ondokuz Mayıs Üniversitesi, Fen Bilimleri Enstitüsü, Bahçe Bitkileri Anabilim Dalı, Yüksek Lisans Tezi, 129 s, Samsun.

Karaağaç, O., \& Balkaya, A. (2010). Bafra kırmızı biber populasyonlarının [ Capsicum annuum L. var. conoides (Mill.) Irish] tanımlanması ve mevcut varyasyonun değerlendirilmesi. Anadolu Tarım Bilimleri Dergisi, 25(1), 10-20.

Karaağaç, O., \& Balkaya, A. (2017). Türkiye'de yerel sebze çeşitlerinin mevcut durumu ve sslah programlarında değerlendirilmesi. TÜRKTOB, 23(6), 8-15.

Kim, S., Park, J., Yeom, S. I., Kim, Y. M., Seo, E., \& Kim, K. T. (2017) New reference genome sequences of hot pepper reveal the massive evolution of plant disease-resistance genes by retroduplication. Genome Biol, 18, 210. https://doi.org/10.1186/s13059-017-1341-9 
Lee, J. M., Nahm, S. H., Kim, Y. M., \& Kim, B. D. (2004). Characterization and molecular genetic mapping of microsatellite loci in pepper. Theoretical and Applied Genetics, 108(4), 619-627.

Lee, S., Kim, S. Y., Chung, E., Joung, Y. H., Pai, H. S., Hur, C. G., \& Choi, D. (2005). EST and microarray analyses of pathogen-responsive genes in hot pepper (Capsicum annuum L.) nonhost resistance against soybean pustule pathogen (Xanthomonas axonopodis pv. glycines). Functional \& integrative genomics, 4(3), 196-205.

Lefebvre, V., Palloix, A., \& Rives, M. (1993). Nuclear RFLP between pepper cultivars (Capsicum annuum L.). Euphytica, 71, 189-199.

Lefebvre, V., Goffinet, B., Chauvet, J. C., Caromel, B., Signoret, P., Brand, R., \& Palloix, A. (2001). Evaluation of genetic distances between pepper inbred lines for cultivar protection purposes: comparison of AFLP, RAPD and phenotypic data. Theoretical and Applied Genetics, 102(5), 741-750.

Moreira, A. F. P., Ruas, P. M., Ruas, C. F., Baba, V. Y., Giordani, W., Arruda, I. M., \& Gonçalves, L. S. A. (2018). Genetic diversity, population structure and genetic parameters of fruit traits in Capsicum chinense. Scientia Horticulturae, 236, 1-9.

Moses, M., Umaharan, P., \& Dayanandan, S. (2014). Microsatellite based analysis of the genetic structure and diversity of Capsicum chinense in the Neotropics. Genetic Resources and Crop Evolution, 61, 741-755.

Moscone, E. A., Scadalferro, M. A., \& Gabriele, M. (2007). The evolution of chili peppers (Capsicum - Solanaceae): a cytogenetic perspective. Acta Horticulturae, 745, 137-169.

Nei, M. (1973). Analysis of gene diversity in subdivided populations. Proceedings of the National Academy of Sciences, 70 (12), 3321-3323.

Okumuş, A., \& Balkaya, A. (2007). Estimation of genetic diversity among Turkish kale populations (Brassica oleracea var. acephala L.) using RAPD markers. ISSN 1022-7954, Russian Journal of Genetics, 43(4), 409-413.

Ortiz, R., \& Delgado, D. L. F. (1990). Utilization of descriptors for the characterization of lines of the genus Capsicum. Turrialba, 40(1), 112-118.

Park, M., Lee, J. H., Han, K., Jang, S., Han, J., Lim, J. H., ... \& Kang, B. C. (2019). A major QTL and candidate genes for capsaicinoid biosynthesis in the pericarp of Capsicum chinense revealed using QTL-seq and RNA-seq. Theoretical and Applied Genetics, 132(2), 515-529.

Ramchiary, N., Kehie, M., Brahma, V., Kumaria, S., \& Tandon, P. (2014). Application of genetics and genomics towards Capsicum translational research. Plant Biotechnol Reports, 8, 101-123.

Röder, M. S., Plaschke, P., Konig, S. U., Borner, A., Sorrells, M. E., Tanksley, S. D., \& Ganal, M. W. (1995). Abundance, variability and chromosomal location of microsatellites in wheat. Molecular and General Genetics, 246, 327-333.

Şensoy, S., \& Şahin, U. (2012). Farklı Sıhke yerel kavun genotipleri arasındaki genetik ilişkiler. Yüzüncü Yll Üniversitesi Tarım Bilimleri Dergisi, 22(3), 147-154.

Qin, C., Yu, C., Shen, Y., Fang, X., Chen, L., \& Min, J. (2014) Whole-genome sequencing of cultivated and wild peppers provides insights into Capsicum domestication and specialization. Proc Natl AcadSci USA, 111, 5135-5140. https://doi.org/10.1073/pnas.1400975111

Uncu, A. T. (2019). Genome-wide identification of simple sequence repeat (SSR) markers in Capsicum chinense Jacq. with high potential for use in pepper introgression breeding. Biologia, 74(2), 119-126.

Yi, G., Lee, J. M., Lee, S., Choi, D., \& Kim, B. D. (2006). Exploitation of pepper EST-SSRs and an SSR-based linkage map. Theoretical and Applied Genetics, 114(1), 113-130.

Yoon, B. J., Jang, C. D., Do, J. W., \& Park, G. H. (2006). Over coming two postfertilisation genetic barriers in inter specific hybridization of anthracnose resistance. Breeding Science, 56, 31-38.

Zhang, X. M., Zhang, Z. H., Gu, X. Z., Mao, S. L., Li, X. X., Chadœuf, J., \& Zhang, B. X. (2016). Genetic diversity of pepper (Capsicum spp.) germplasm resources in China reflects selection for cultivar types and spatial distribution. Journal of integrative agriculture, 15(9), 1991-2001.

Zewdie, Y., \& Zeven, A. C. (1997). Variation in Yugoslavian hot pepper (Capsicum annuиm L.) Accessions. Euphytica, 97, 81-89.

Zhu, Z., Sun, B., Wei, J., Cai, W., Huang, Z., Chen, C., \& Lei, J. (2019). Construction of a high density genetic map of an interspecific cross of Capsicum chinense and Capsicum annuum and QTL analysis of floral traits. Scientific reports, 9(1), 1-14. 